\title{
Policy Evaluation of Village Head Election in Bandung Regency
}

\author{
Deddy Mulyadi ${ }^{1}$, Riky Maulana ${ }^{2}$ \\ Polytechnic of STIA LAN Bandung ${ }^{12}$ \\ \{deddymulyadi@poltek.stialanbandung.ac.id ${ }^{1}$,riky.rinaldy@poltek.stialanbandung.ac.id²
}

\begin{abstract}
Head of village elections are currently being held simultaneously by local governments referring to Undang-Undang Desa No 6 Tahun 2014 and Peraturan Menteri Dalam Negeri Nomor 65 Tahun 2017 concerning Village Head Elections, this is the basis for implementing simultaneous head of village elections, in 2019 one of the regions in West Java, namely Bandung Regency, held simultaneous head of village elections in 119 villages. The implementation of this simultaneous head of village elections is a big enough attraction where in the implementation of this village head election various problems arise from public complaints about the implementation of the simultaneous head of village elections. This research uses descriptive qualitative research methods, with data collection techniques through direct observation, and in-depth interviews. The Bandung Regency Government sees that there are obstacles in the implementation of the third wave of simultaneous head of village elections where there are many complaints from various parties related to dissatisfaction with the results of the vote count and the performance of the head of village elections committee. Therefore, an evaluation of the implementation of this policy is something that is needed so that the simultaneous head of village elections in 2021 can be improved for the next elections.
\end{abstract}

Keywords: Evaluation Policy; Public Policy

\section{Introduction}

This Indonesia is one of the countries in the world that implements a democratic political system. Democracy in Indonesia has a slogan that is quite short, but has a deep meaning. The slogan is "from the people, by the people, and for the people". Reflecting on the slogan, we can see that the democracy implemented in Indonesia is democracy, where one example of the manifestation of democracy is the existence of a democratic party, namely the General Election (Pemilu). Village head elections are part of general elections held in Indonesia in addition to presidential elections, governor elections, regent or mayor elections, and elections for the people's representative council.

Village head elections are currently being held simultaneously by local governments, referring to Undang-Undang Desa No 6 Tahun 2014 and Peraturan Menteri Dalam Negeri Nomor 65 Tahun 2017 concerning Village Head Elections. This is the basis for implementing simultaneous village head elections. One of the momentum for village development is the election of village heads as a form of implementing democratic principles in village government. As stipulated in the Peraturan Menteri Dalam Negeri Republik Indonesia Nomor 65 Tahun 2017 concerning Village Head Elections, that the Village Head Election is carried out simultaneously or it can be bumpy. 
Elections for Village Heads are carried out simultaneously in all Regency/City areas with the principles of direct, general, free, confidential, honest and fair. With the direct election of the Village Head, it shows that the highest leadership in the village must be the majority agreement of the villagers concerned, so that it will be able to increase community participation or participation in village development. This is also interpreted as a political learning process for the village community.

The simultaneous election of the Village Head also aims for educating the village community in order participate directly to avoid feudal culture and to allow elite circulation at the village level, so that democratic wisdom will grow in the village community. The existence of the principle of democracy in the simultaneous election of the Village Head does not cause the principle of deliberation that has been rooted in the culture of the village community to disappear.

However, the principle of deliberation is also carried out through the village deliberation mechanism in the interim Village Head election. So that with this mechanism, the rights of the village community are really considered which in the end will provide opportunities for the community to continue to actively participate in the implementation of Village Government. In 2019, one of the regions in West Java, namely Bandung Regency, held simultaneous village head elections in 119 villages. The implementation of this simultaneous village head election is a big enough attraction where in the implementation of this village head election various problems arise from public complaints about the implementation of the simultaneous village head election.

The election of Village Heads in Bandung Regency is based on Bandung Peraturan Bupati Bandung Nomor 9 Tahun 2019 Perubahan Atas Peraturan Bupati Nomor 3 Tahun 2015 Tentang Petunjuk Pelaksanaan Peraturan Daerah Kabupaten Bandung Nomor 19 Tahun 2014 Tentang Pemilihan Dan Pemberhentian Kepala Desa Di Kabupaten Bandung. Bandung Regency has held simultaneous village head elections (pilkades) in 199 villages in 2019, One of the districts in West Java that held Pilkades with many villages, besides that the implementation of this village head election became a very conflict-prone matter, where in the election of Villages in 2019 in this district there were conflicts or disputes that occurred in the determination of the DPT and when counting the votes

\section{Theoretical Framework}

\subsection{Evaluation Policy}

Policy Evaluation To assess the extent of the impact of implementing public policies as the government's accountability to the community, as well as the extent to which policy objectives have been achieved and seeing the extent of the gap between expectations and reality, evaluation is usually required. According to Anderson (Winarno, 2007:166): in general, the evaluation of this policy can be said as an activity that involves the assessment of a policy implementation which includes the substance, implementation, and impact of the implementation of the policy.

According to Lester and Stewart (Winarno, 2007:166): "Policy evaluation can be divided into two different tasks, the first task is to determine the consequences caused by a policy by describing its impact. While the second task is to assess the success or failure of a policy based on predetermined standards or criteria. Policy evaluation is a matter of fact in the form of measuring and assessing both the implementation stage of the policy and the outcome or impact 
of the operation of a particular policy or program, to determine the steps that can be taken in the future.

Types of Policy Evaluation James Anderson in Winarno (2007: 229) divides policy evaluation into 3 (three) types, each type of evaluation introduced is based on the evaluators' understanding of evaluation, as follows:

a. The first type: Policy evaluation is understood as a functional activity. If policy evaluation is understood as a functional activity, policy evaluation is seen as an activity that is as important as the policy itself.

b. The second type: This type is evaluation that focuses on the policy performance or specific program. This type of evaluatation is more to discuss about honesty and eficiency in order to run policy program.

c. Third type: Systematic policy evaluation type. This type of policy sees objectively the policy programs that are implemented to measure their impact on the community and see how far the stated objectives have been achieved. Of the three types, the type of systematic policy evaluation is considered the most appropriate for this research. Researchers want to see how far the impact of the implementation of the tourism industry development policy on the community, whether the policies implemented have achieved the stated goals, what factors are the supporting and inhibiting factors in implementing the policy.

William N. Dunn (2003: 609) suggests several policy recommendation criteria which are the same as the policy evaluation criteria, the policy recommendation criteria consist of:

a. Effectiveness. Relating to an alternative achieving an expected result or achieving a goal of implementing a policy action. Effectiveness is closely related to technical rationality, always measured by a policy or service.

b. Efficiency is the amount of effort required to produce a certain level of effectiveness.

c. Adequacy relates to the extent to which a level of effectiveness matches a need, value, or opportunity to create a problem. This criterion of adequacy emphasizes the strong relationship between policy alternatives and expected outcomes.

d. Equalization, closely related to legal and social rationality and refers to the distribution of effects and efforts between different groups in society.

e. Responsiveness is concerned with the extent to which a policy can satisfy the needs, preferences, or values of certain community groups. the responsiveness criterion is very important.

f. Accuracy. The classification of appropriateness is closely related to rationality, substantive, because the question of policy appropriateness is not concerned with an individual set of criteria but two or more criteria together. In this case, accuracy refers to the value or price of the program objectives and to the strength of the assumptions that underlie these goals.

Evaluation is an important stage in program implementation. Positive benefits will be obtained if the evaluation is carried out properly and pays attention to all aspects of a program. According to Dunn, 2003: 609-611, it has several main functions in policy analysis, namely:

a. Evaluation will make the data valid and reliable in the field of information policy performance such as, how far needs, values and opportunities have been achieved through public action.

b. Evaluation effects to the clarification and critique of the values that underlie the selection of goals and targets. Values are clarified by defining and operating goals and targets. Values are also criticized by systematically asking the appropriateness of goals and targets in relation to the problem at hand. In asking the appropriateness of goals and objectives, the 
analyst can examine alternative sources of value (e.g., interest groups and civil servants, client groups) as well as their basis in various forms of rationality (technical, economic, legal, social, substantive).

c. Evaluation contributes to the clarification and critique of the values that underlie the selection of goals and targets. Values are clarified by defining and operating goals and targets. Values are also criticized by systematically asking the appropriateness of goals and targets in relation to the problem at hand. In asking the appropriateness of goals and objectives, the analyst can examine alternative sources of value (e.g., interest groups and civil servants, client groups) as well as their basis in various forms of rationality (technical, economic, legal, social, substantive).

Evaluation can also contribute to the definition of a new policy alternative or a revised policy by showing that the previously favored policy alternative needs to be removed and replaced with another. In addition to the above, following Samodra Wibawa (1994: 10-11), the evaluation of public policies has 4 (four) functions, namely:

a. Explanation

Through evaluation, a portrait of the reality of program implementation can be made and generalizations can be made about the patterns of relationships between the various dimensions of reality that are observed. From this evaluation, the evaluator can identify problems, conditions, and actors that support the success or failure of the policy.

b. Obedience

Through evaluation, it can be seen whether the actions taken by the actors, both bureaucrats and other actors, are in accordance with the standards and procedures set by the policy.

c. Audit

Through the audit, it can be known whether the outputs reach the policy target groups, or there are leaks or irregularities.

d. Accounting

With the evaluation, it can be seen what the socio-economic consequences of the policies that have been implemented.

\section{Methods}

The method used in this research is descriptive qualitative. The data collection technique used in this research is to make observations in Bandung Regency government environment, especially in the DPMD and Village Government environments, in-depth interviews with several sources who understand this research, and literature study by collecting documents that support this research. From the data collection method used data analysis techniques in the form of a combination of all the data used. Data collection in this activity consists of secondary data and primary data. Secondary data is directed at documents related to local organizations. While primary data is directed to collect information directly in the field.

\section{Research Findings and Discussions}

This evaluation of the Village Head Election Policy is to assess the effectiveness of the implementation of the village head election conducted by the Bandung Regency government which aims to be accountable to its constituents, as well as the extent to which the policy 
objectives have been achieved, and to see how far the gap between expectations and reality is, it is usually necessary to evaluate to see the impact of village head election activities.

Therefore, the evaluation of the village head election is seen from the concept of policy evaluation, according to William N. Dunn (2003: 609) suggests several policy recommendation criteria that are the same as the policy evaluation criteria to see the impact of the implementation of the village head election.

\subsection{Explanation}

This 2019 Simultaneous Village Head Election is the third time for the Bandung Regency Government. Therefore an evaluation is needed so that the problem can be seen as a whole and in order to improve the implementation of future activities which will be carried out in 2021 . Simultaneous village head elections in Bandung Regency on the year 2019 has stepped into the third wave where previously two waves have been carried out, namely:

a. Phase I was carried out in 2015 with 48 villages participating.

b. Phase II was carried out in 2017 with 22 villages participating.

c. Phase III was carried out in 2019 with 199 villages as participants from the previous plan of 200 villages, because 1 village will not participate in the simultaneous Pilkades in 2019.

In the implementation of this stage III simultaneous village head election, the main actor in its implementation is the district level simultaneous village head election committee which has the tasks such as:

a. Plan, coordinate, and organize all stages of the implementation of the Village Head Election at the Regency level.

b. Provide technical guidance for the implementation of the Village Head Election to the Village Head Election committee at the Village level.

c. Facilitating the resolution of problems in the Village Head Election at the Regency level.

d. Supervise the implementation of the Village Head Election and report and make recommendations to the Regent; and

e. Evaluate and report on the implementation of the Village Head Election.

Therefore, this village election committee became the main actor of success in the implementation of the village head election in Bandung district which in 2019 ran smoothly and in accordance with the predetermined planning.

\subsection{Obedience}

The implementation of the village head election in Bandung Regency in 2019 went quite well where in its implementation it was carried out by the simultaneous village head election committee at the district level, namely with the PMD Office program and activities through the DPMD Government Sector, a series of Bimtek or Santiaji activities had been carried out in order to strengthen organizing the simultaneous Pilkades Phase III of 2019 for the Pilkades Committee, BPD and the Supervisory Committee throughout the Bandung Regency area.

This activity was carried out for 6 batches with one day for each class, starting from Wednesday, July 30, 2019, at the Sutan Raja Hotel Soreang, 5-6 August 2019 at the Clove Garden Hotel Cimenyan, 7 August 2019 at the Sutan Raja Hotel. Afternoon, and August 8-9 at Hotel Sahid Sunshine Soreang. The speakers were the Head of DPMD, Chairman of Commission A DPRD, Secretary of the Kesbangpol Agency, Head of the Legal Division, Academics from IPDN DR. Fernandes Simangunsong, S.STP, S.AP, M.Si, Widyaiswara from West Java Province, Chairman and Members of the Bandung Regency KPU and Head of the Governance Section. 
The participants for technical guidance/santiaji were 977 people consisting of the Secretary of the Camel, Head of District Administration, BPD, the Pilkades Committee, and the Subdistrict Panwas which also consisted of members of the Koramil and Polsek in the Bandung Regency area. In addition, to support the needs of the Pilkades organizers, they will issue a practical guideline which is the 2019 Simultaneous Pilkades Implementation Guidebook which is expected to increase the smooth implementation of the tasks of the Pilkades Committee and the Pilkades Supervisory Committee, to overcome the high dynamics in the implementation of health and psychological tests for residents.

Prospective village heads, in droves of prospective candidates visiting hospitals while the capacity of hospitals is limited, coordination has been carried out with the Health Office and Bandung Regency Hospitals, namely Soreang, Majalaya and Cicalengka hospitals to seek scheduling in its implementation by dividing zoning based on area and capacity. each so that it is expected to run effectively.

\subsection{Audit}

At the time of the implementation of the simultaneous village head elections, the nomination stages were carried out in each village with 836 participants. The dynamics arose regarding the verification process for the required documents which eventually dropped several prospective candidates, such as in Sekarwangi Village, Soreang Subdistrict, Panyocokan Village, Ciwidey Subdistrict and Melatiwangi Village, Cilengkrang Subdistrict, with the handling of the Panwas with the Regency Team finally being resolved. Simultaneously also coordinated on the preparation of the implementation of the written selection in collaboration with Universities that match the qualifications.

After going through a fairly tough process, finally the written examination could be held with FISIP UNPAD for 307 people from 46 villages in 22 sub-districts on Thursday 5 September 2019. The results of the written selection were delivered at that time in the evening to the P2KD and Panwas Chairs.The policy of simultaneous village head elections in Bandung Regency should have been ideal because it has been implemented for the third time.

However, in its implementation, there are still problems, such as the verification process for the required documents which eventually aborted several prospective candidates, such as in Sekarwangi Village, Soreang District, Panyocokan Village, Ciwidey District and Melatiwangi Village, Cilengkrang District, with the handling of the Panwas together with the Regency Team.

In addition, it also emerged after the determination of the results of additional selection and written tests due to lack of understanding of P2KD on the formulation of calculating additional selection indicators, as happened in Cileunyi Wetan Village, Cinunuk Village, Cileunyi District and Karangtunggal Village, Paseh District. Conditions in Karangtunggal Paseh required a long security process from the police and military.

With intense handling from the Panwas and the Regency Team, the problem was finally resolved, and the determination of candidates could be carried out in all villages in Bandung Regency. Ahead of the campaign period, several events occurred including, the application for the postponement of the campaign period because it coincided with the inauguration of the President and Vice President, then the withdrawal of TNI and Polri troops from the Panwas membership which was then followed up with Circular Letters of the Regent regarding the process of delaying the campaign period, withdrawing the TNI and Polri.

From the membership of the Panwas and in addition to a Circular on the application for compensation for employees in carrying out the collection. The implementation of voting and vote counting was carried out simultaneously in 199 villages throughout Bandung Regency with the participation of various implementing, supervisory, security and monitoring elements. 
The opportunity to monitor Forkopimda and OPD was directly led by the Regent of Bandung to several polling stations in six sub-districts, namely Gunung Leutik Village (Ciparay District), Sukamaju Village (Majalaya District), Tangsimekar Village (Paseh District), Solokanjeruk Village (Solokanjeruk District), Rancaekek Wetan Village (Kec.Rancaekek) and Cileunyi Wetan Village (Cileunyi District).

Finally, the problems that arise 22. After the implementation of voting and vote counting, it was discovered that several villages had problems based on recorded complaints (data as attached). Some villages that require more handling are provided with assistance, such as Bojongloa Village and Haurpugur Village, Rancaekek Sub-district, Citeureup Village, Dayeuhkolot District, Karangtunggal Village, Paseh District and Cinunuk Village, Cileunyi District. Until now, except for Citeureup Village, Dayeuhkolot District, it is still in the process of being handled by the respective District Supervisory Committees who are accompanied by Forkopimcam and assistance from the Bandung Regency Level Team.

\subsection{Accounting}

The implementation of this simultaneous village head election is an interesting thing to see in its implementation because the impact that results from the simultaneous village head election has an impact in the short and long term, where the short-term impact in the implementation of the village head election focuses more on the conflicts that occur. in the community when the implementation of the village head election is not in accordance with the policy or there are irregularities that can result in considerable problems for the administration of the village government and have a negative impact, but the positive impact of the simultaneous village head election is seeing the level of community participation in contributing to village development and also implementation that can be carried out simultaneously so as to facilitate the district government in the implementation of village head elections.

The impact of implementing the simultaneous village head elections is quite large for regional development because the village head election is very important and crucial where the village head becomes a very strategic role holder in making regional development planning. village. In addition, the role of the community in the election of village heads is very significant seen from the campaign period until the election takes place where the community participates directly, this proves that in this simultaneous village head election role can increase community participation and foster a sense of community ownership of the area where the community is located.

\section{Conclusion}

The implementation of the simultaneous Pilkades in Bandung Regency requires some improvements, especially in implementing policies because there are still various problems that occur. In addition, changes to the regent's regulations must be made because there are several regulations that need to be updated so that they can be a strong reference during the simultaneous village head elections.

\section{References}

[1] Budi Winarno, 2007. Kebijakan Publik: Teori dan Proses, (Edisi Revisi),Yogyakarta: Media Pressindo

[2] Dunn, William N, 2003 : Kebijakan dan Kebijakan Publik, Bandung

[3] Samodra Wibawa, 1994, Kebijakan Publik :Proses dan Analisis, Cet.Ke-1, Jakarta: Intermedia 